Postgraduate Bosowa University Publishing (PBUP)
Indonesian Journal of Business and Management
e-ISSN: $2460-3767 \quad p$-ISSN: $2656-6885$
Pttps://postgraduate.universitasbosowa.ac.id/index.php/jbm

\title{
PENGARUH KOMITMEN ORGANISASI DAN LINGKUNGAN KERJA TERHADAP KINERJA PEGAWAI MELALUI KEPUASAN KERJA PADA KANTOR PEMERINTAH KECAMATAN CAMBA KABUPATEN MAROS
}

\section{The Influence of Organizational Commitment and Working Environment on Employee Performance through Work Satisfaction in Government Office of Camba District Maros Regency}

\author{
Kemal Wahyudi $^{1}$, Muhlis Ruslan ${ }^{2}$, Chahyono ${ }^{2}$ \\ ${ }^{1}$ Kelurahan Campaniga Kecamatan Camba, Kabupaten Maros \\ ${ }^{2}$ Program Studi Manajemen Program Pascasarjana Universitas Bosowa \\ Email: kemal_wah@yahoo.co.id
}

Diterima: 22 Januari 2021/Disetujui: 02 Juni 2021

\begin{abstract}
ABSTRAK
Persaingan yang semakin ketat menyebabkan organisasi mampu meningkatkan daya saing serta berani meng-hadapi tantangan dan implikasinya yaitu menghadapi perubahan-perubahan dalam mencapai tujuan dan sasaran yang ditetapkan oleh organisasi tersebut. Tujuan dari penelitian ini adalah untuk mengetahui dan menganalisis pengaruh Komitmen organisasi, lingkungan kerja terhadap kepuasan kerja pegawai, pengaruh Komitmen organisasi dan lingkungan kerja terhadap kinerja pegawai, pengaruh kepuasan kerja terhadap kinerja pegawai, pengaruh komitmen organisasi, dan lingkungan kerja terhadap kinerja melalui kepuasan kerja. Teknik pengumpulan data melalui interview dan kuesioner. Populasi dalam penelitian ini adalah pegawai Kantor Kecamatan Camba berjumlah sebanyak 57 orang pegawai, sedangkan teknik penentuan sampel meng-gunakan sampling jenuh. Teknik analisis data yang digunakan adalah analisis deskriptif kuantitatif, uji instrument penelitian, uji asumsi klasik, analisisi jalur (Path analisis), pengujian hipotesis. Hasil penelitian menunjukkan bahwa (1) komitmen organisasi berpengaruh positif dan signifikan terhadap kepuasan kerja, artinya semakin tinggi komitmen organisasi berarti semakin puas pegawai dalam bekerja. (2) Lingkungan kerja berpengaruh positif dan signifikan terhadap kepuasan kerja, artinya semakin baik penataan lingkungan kerja maka kepuasan kerja akan semakin meningkat. (3) Komitmen organisasi berpengaruh positif dan signifikan terhadap kinerja pegawai, artinya semakin tinggi komitmen organisasi maka mempengaruhi peningkatan kinerja pegawai, (4) Lingkungan kerja berpengaruh positif dan signifikan terhadap kinerja pegawai, artinya semakin baik penataan lingkungan kerja maka akan mendorong peningkatan kinerja karyawan. (5) Kepuasan kerja berpengaruh positif dan signifikan tehadap kinerja pegawai, artinya semakin pegawai merasa puas maka akan berpengaruh terhadap peningkatan kinerja. (6) Kepuasan kerja tidak dapat memediasi pengaruh komitmen organisasi terhadap kinerja pegawai (7) Kepuasan kerja dapat memediasi pengaruh lingkungan kerja terhadap kinerja pegawai.
\end{abstract}

Kata Kunci: Komitmen Organisasi, Lingkungan Kerja, Kepuasan Kerja dan Kinerja Pegawai

\begin{abstract}
Increasingly tighter competition causes the organization to increase its competitiveness and dare to face challenges and its implications, such as facing changes in achieving the goals and objectives set by the organization. The purpose of this study was to determine and analyze the influence of organizational commitment, work environment on employee job satisfaction, the influence of organizational commitment and work environment on employee performance, the influence of job satisfaction on employee performance, the influence of organizational commitment, and work environment on performance through job satisfaction. Data was collected through interviews and questionnaires. The population in this study were 57 employees of Camba District Office, while the sampling technique used saturated sampling. The data analysis technique used is descriptive quantitative analysis, research instrument test, classical assumption test, path analysis, and hypothesis testing. The results show that (1) organizational commitment has a positive and significant effect on job satisfaction,
\end{abstract}


meaning that the higher the organizational commit-ment, the more satisfied employees are at work. (2) The work environment has a positive and significant effect on job satisfaction, meaning that the better the arrangement of the work environment, the more job satisfaction will increase. (3) Organizational commitment has a positive and significant effect on employee performance, meaning that higher organizational commitment will affect employee performance improvement, (4) The work environment has a positive and significant effect on employee performance, meaning that better arrangement of the work environment will encourage the increase of employee performance. (5) Job satisfaction has a positive and significant effect on employee performance, meaning that more satisfied employees will have an effect on improving their performance. (6) Job satisfaction cannot mediate the effect of organizational commitment on employee performance. (7) Job satisfaction can mediate the influence of the work environment on employee performance.

Keywords: Organizational Commitment, Work Environment, Job Satisfaction And Employee Performance

\section{PENDAHULUAN}

Menghadapi persaingan di era globalisasi saat ini menuntut setiap organisasi baik di bidang swasta maupun pemerintah untuk bekerja lebih efisien dan efektif. Persaingan yang semakin ketat menyebabkan organisasi mampu meningkatkan daya saing serta berani menghadapi tantangan dan implikasinya yaitu menghadapi perubahan-perubahan dalam mencapai tujuan dan sasaran yang ditetapkan oleh organisasi tersebut. Untuk mencapai tujuan dari organisasi, maka diperlukan sumber daya. Menurut Sutrisno (2016) sumber daya manusia merupakan satu-satunya sumber daya yang memiliki akal, perasaan, keinginan, keterampilan, pengetahuan, dorongan, daya, dan karya (rasio, rasa dan karsa). Semua potensi sumber daya manusia tersebut berpengaruh terhadap upaya organisasi dalam mencapai tujuan. Sumber daya yang dimiliki oleh suatu organisasi tidak bisa memberikan hasil yang optimum apabila tidak didukung oleh sumber daya manusia yang mempunyai kinerja (job performance) yang tinggi.

Prawirosentono (2017) mengatakan bahwa kinerja adalah hasil kerja yang dapat dicapai oleh seseorang atau sekelompok orang dalam suatu organisasi sesuai dengan wewenang dan tanggungjawab masing-masing dalam rangka upaya mencapai tujuan organisasi bersangkutan. Karyawan yang memiliki kinerja kerja yang tinggi atau memberikan kontribusi yang optimal pada perusahaan karena adanya kepuasan kerja yang dirasakan oleh karyawan dalam bekerja. Kepuasan kerja merupakan dambaan setiap karyawan yang sudah bekerja. Masingmasing karyawan memiliki tingkat kepuasan yang berbeda sesuai dengan nilai yang dianutnya. Semakin banyak aspek-aspek dalam pekerjaan yang sesuai dengan keinginan dan kebutuhan karyawan tersebut maka semakin tinggi pula kepuasan kerja yang dirasakan, demikian pula sebaliknya. Sinambela (2012) mengatakan bahwa kepuasan kerja berkaitan erat dengan kinerja pegawai, alasannya karena kepuasan kerja merujuk kepada sikap umum seorang individu atau karyawan terhadap pekerjaan yang dilakukannya. Seseorang dengan tingkat kepuasan kerja tinggi menunjukkan sikap yang positif terhadap pekerjaan itu sendiri, sedangkan seseorang yang tidak puas dengan pekerjaannya menunjukkan sikap yang negatif terhadap pekerjaan itu. Sehingga dapat dikatakan bahwa kepuasan kerja yang tinggi akan berpengaruh terhadap kinerja karyawan.
Penelitian Robbins dan Judge (2015) menjelaskan dari 300 studi yang dilakukan terdapat korelasi yang cukup kuat antara kepuasan kerja dan kinerja, dimana sebuah organisasi dengan lebih banyak pegawai yang lebih puas cenderung lebih efektif menghasilkan kinerja kerja jika dibandingkan organisasi yang lebih sedikit pegawai merasakan kepuasan kerja.

Oleh karena itu untuk meningkatkan kepuasan kerja dan kinerja pegawai maka perlunya komitmen organisasi. Luthans (2012) berpendapat bahwa komitmen organisasi merupakan sikap yang merefleksikan loyalitas karyawan pada organisasi dan proses berkelanjutan di mana anggota organisasi mengekspresikan perhatiannya terhadap organisasi dan keberhasilan serta kemajuan yang berkelanjutan. Pegawai dengan komitmen yang tinggi dapat diharapkan mampu menunjukkan kinerja yang optimal. Seseorang yang bergabung pada organisasi dituntut adanya komitmen dalam dirinya, karena dengan adanya komitmen tersebut maka akan tumbuh motivasi untuk mencapai suatu tujuan dan apabila pencapaian tujuan tersebut terpenuhi maka akan menimbulkan kinerja yang baik pada pegawai tersebut. Jadi komitmen organisasi merupakan sikap para pegawai berkaitan dengan keterlibatannya dalam organisasi, kesetiaannya dengan organisasi dan rasa menjadi bagian organisasi. Penelitian Riswanto (2013) menunukkan bahwa komitmen organisasi, kepuasan kerja dan kinerja merupakan hal yang tidak terpisahkan dari sebuah organisasi, karena dalam suatu organisasi membutuhkan hal-hal yang bisa memotivasi karyawan agar bisa bekerja dengan baik dan benar sehingga tujuan dari orgaisasi bisa tercapai dan mendapatkan hasil yang bagus. Semakin baik komitmen organisasi maka semakin baik kinerja kerja melalui kepuasan kerja yang dirasakan oleh karyawan.

Selain komitmen, maka lingkungan kerja mempengaruhi kepuasan kerja dan kinerja pegawai. Afandi (2018) mengemukakan bahwa lingkungan kerja merupakan faktor yang sangat penting di dalam perusahaan. Lingkungan kerja yang baik akan mendukung adanya tingkat produktivitas kerja yang tinggi, sehingga akan dapat meningkatkan produktivitas dari perusahaan yang bersangkutan. Lingkungan kerja yang menyenangkan bagi karyawan akan dapat menimbulkan rasa bergairah dalam bekerja sehingga memberikan kepuasan kerja bagi karyawan. Lingkungan kerja selain memberikan pengaruh terhadap kepuasan kerja pegawai, juga dapat berpengaruh dalam peningkatan 
kinerja pegawai sebagaimana dikemukakan oleh Afandi (2018) bahwa lingkungan kerja yang kondusif memberikan rasa aman dan memungkinkan karyawan untuk dapat bekerja optimal. Jika karyawan menyenangi lingkungan kerja dimana dia bekerja, maka karyawan tersebut akan betah di tempat kerjanya, melakukan aktivitasnya sehingga waktu kerja dipergunakan secara efektif. Sebaliknya lingkungan kerja yang tidak memadai akan dapat menurunkan kinerja karyawan. Pemilihan kepuasan kerja menjadi pemoderasi bagi pengaruh komitmen organisasi dan lingkungan kerja terhadap kinerja pegawai, untuk mengetahui apakah kepuasan kerja mampu memperkuat atau melemahkan pengaruh komitmen organisasi dan lingkungan kerja terhadap kinerja pegawai. Penelitian Lestari, dkk. (2014) menemukan bahwa kepuasan kerja secara signifikan memoderasi pengaruh komitmen organisasi dan lingkungan kerja terhadap kinerja karyawan di departemen akuntansi.

Kepuasan kerja menjadi pemoderasi bagi pengaruh komitmen organisasional dan lingkungan kerja terhadap kinerja karyawan, yang mampu menguatkan ataupun melemahkan pengaruh komitmen organisasional dan lingkungan kerja terhadap kinerja karyawan. Riswanto (2013)hasil temuan bahwa semakin baik komitmen organisasi, semakin baik kinerja melalui kepuasan karyawan dapat diterima karena pengaruh tidak langsung dari komitmen organisasi terhadap kinerja melalui kepuasan lebih besar daripada pengaruh langsung komitmen organisasi terhadap kinerja karyawan. Begitu pula Lestari, dkk. (2014) hasil penelitian menunjukkan bahwa kepuasan kerja secara signifikan memoderasi pengaruh komitmen organisasi terhadap kinerja karyawan di departemen akuntansi, dan kepuasan kerja tidak signifikan memoderasi pengaruh Lingkungan kerja dan kompetensi terhadap kinerja karyawan di departemen akuntansi.

Pentingnya masalah komitmen organisasi dan lingkungan kerja, maka penelitian ini dilakukan pada Kantor Pemerintah Kecamatan Camba Kabupaten Maros, yang merupakan organisasi pemerintahan yang mengemban misi tugas pelayanan di bidang pemerintahan, pembangunan dan pembinaan kemasyarakatan yang bersentuhan langsung dengan masyarakat sehingga dituntut untuk semakin profesional dalam pemberian jasa layanan publik. Oleh karena itu maka Kantor Kecamatan Camba berupaya untuk meningkatkan kinerja dari masing-masing pegawai. Namun permasalahan yang terjadi bahwa kinerja pegawai belum optimal. Masalah yang berkaitan dengan kinerja adalah tingginya ketidakhadiran pegawai karena kurangnya kesadaran atau komitmen organisasi yang masih rendah pada setiap pegawai. Selain itu kurangnya pengawasan terhadap pegawai dalam bekerja hanya dengan menggunakan presensi secara online ketika awal masuk (pagi) dan selesai kerja (sore) memberikan celah bagi pegawai untuk keluar kantor pada siang hari tanpa ijin dari atasan.
Kemudian fenomena lainnya terkait dengan lingkungan kerja, yakni kurangnya kenyamanan dalam bekerja. Hal ini dapat dilihat dari sikap rekan kerja yang kurang bekerja sama dengan pegawai lainnya, desain tempat kerja atau ruang pada masing-masing bidang belum dipisah-pisahkan sehingga hal ini berpengaruh terhadap aktivitas kerja sehari-hari. Oleh karena itu dengan adanya permasalahan yang terjadi maka perlunya dilakukan evaluasi mengenai komitmen organisasi dan lingkungan kerja terkait dengan permasalahan yang terjadi pada kantor Pemerintah Kecamatan Camba Kabupaten Maros.

\section{METODE}

a. Jenis Penelitian

Pendekatan dalam penelitian ini adalah pendekatan deskriptif dan asosiatif, karena adanya variabel-variabel yang akan ditelaah hubungannya serta tujuannya untuk menyajikan gambaran secara terstruktur, faktual, dan akurat mengenai fakta-fakta serta hubungan antar variabel yang diteliti melalui pengujian hipotesis. Kemudian apabila data telah diperoleh akan dikelola, diolah, dianalisis dan diproses lebih lanjut dengan dasar teori yang telah dipelajari. Sedangkan analisis digunakan dengan menggunakan metode statistik yang relevan untuk menguji hipotesis mengenai komitmen organisasi dan lingkungan kerja terhadap kinerja pegawai melalui kepuasan kerja pada Kantor Pemerintah Kecamatan Camba Kabupaten Maros.

b. Lokasi Penelitian

Dalam penelitian ini peneliti akan melakukan penelitian di pada Kantor Pemerintah Kecamatan Camba Kabupaten Maros.

c. Populasi dan Sampel

Populasi dalam peneleitian ini adalah pengawai yang bekerja pada Kantor Pemerintah Kecamatan Camba Kabupaten Maros yang berjumlah sebanyak 57 orang pegawai yang dapat diperincikan : Kantor Kecamatan Camba sebanyak 30 orang, Kelurahan Campaniaga 14 orang dan Kelurahan Mariopulana 13 orang. Sedangkan jumlah keseluruhan sampel adalah sebanyak 57 orang, selanjutnya untuk menentukan jumlah sampel maka digunakan metode sampling jenuh dimana menurut Sugiyono (2016:69), bahwa metode sampling jenuh digunakan apabila populasi kurang dari 100 maka jumlah populasi yang ada dapat dijadikan sebagai jumlah keseluruhan sampel dalam penelitian ini. Mengacu dari uraian tersebut di atas maka penelitian ini ditentukan sampel sebanyak 57 orang responden.

d. Variabel Penelitian

Variabel yang digunakan dalam penelitian ini adalah komitmen organisasi $\left(\mathrm{X}_{1}\right)$ dan lingkungan kerja $\left(\mathrm{X}_{2}\right)$ yang dijadikan sebagai variabel bebas, kemudian kinerja pegawai (Y) dijadikan sebagai variabel terikat. Sedangkan kepuasan kerja $(\mathrm{Z})$ merupakan variabel moderasi yang tujuannya untuk memperkuat atau memperlemah antara variable bebas dan variable terikat. 
e. Teknik Pengumpulan Data

Teknik pengumpulan data yang digunakan oleh peneliti dalam penelitian ini adalah : a. Wawancara (Interview), yaitu teknik pengumpulan data dengan mengadakan tanya jawab atau wawancara langsung dengan para pegawai yang berwenang dilingkungan dinas pemerintahan untuk mengumpulkan data mengenai objek yang diteliti. b. Pengamatan Langsung (Observasi), yaitu teknik pengumpulan data dengan cara melakukan pengamatan langsung pada objek penelitian untuk memperoleh data yang diperlukan. c. Kuesioner, yaitu teknik pengumpulan data yang dilakukan dengan memberikan daftar pertanyaan untuk diisi oleh para responden dan diminta untuk memberikan pendapat atau jawaban atas pertanyaan yang diajukan sebanyak 57 eksamplar, dan d. Dokumentasi, merupakan teknik penelitian dimana peneliti mengumpulkan data-data yang diperlukan sehubungan dengan penelitian berupa surat keputusan dan formulir yang digunakan organisasi.

f. Jenis dan Sumber Data

Jenis dan sumber data terdiri dari data kualitatif, yaitu data yang diperoleh dari pada Kantor Pemerintah Kecamatan Camba Kabupaten Maros, seperti sejarah singkat berdirinya pada Kantor Pemerintah Kecamatan Camba Kabupaten Maros, struktur organisasi dan uraian tugas, sedantgkan Data kuantitatif, yaitu data yang diperoleh dalam bentuk angka-angka yang masih perlu dianalisis antara lain mengenai komitmen organisasi dan lingkungan kerja terhadap kinerja pegawai melalui kepuasan kerja. Sedangkan sumber data terdiri dari data primer, yakni data yang diperoleh peneliti baik dari hasil wawancara atau hasil pengisian kuisioner. Dalam penelitian ini untuk mendapatkan data primer dapat dilakukan dengan cara penyebaran kuesioner langsung kepada pegawai. Sedangkan data sekunder adalah data yang telah diolah lebih lanjut dan disajikan baik oleh pihak pengumpul atau oleh pihak lain. Data sekunder dalam penelitian ini diperoleh dari data-data Kantor Pemerintah Kecamatan Camba Kabupaten Maros serta data lainnya yang menunjang penelitian ini.

g. Teknis Analisis Data

Metode analisis yang digunakan dalam penelitian ini adalah sebagai berikut :

1. Analisis Deskriptif

Analisis deskriptif yaitu suatu analisis yang menggambarkan atau menguraikan pengaruh komitmen organisasi dan lingkungan kerja terhadap kinerja pegawai melalui kepuasan kerja pada Kantor Pemerintah Kecamatan Camba Kabupaten Maros, melalui kuesioner yang disebarkan kepada sejumlah responden dalam penelitian ini.

2. Uji Instrumen Penelitian

a. Uji Validitas adalah suatu alat ukur yang menunjukkan kesesuaian dari alat ukur tersebut yaitu item-item pernyataan dalam kuesioner, dengan apa yang ingin diukur. Dimana butir pernyataan yang valid digunakan apabila nilai $r=0,30$. b. Uji reliabilitas digunakan untuk mengetahui konsistensi alat ukur, apakah alat pengukur yang digunakan dapat diandalkan dan tetap konsisten jika pengukuran tersebut diulang. Uji reliabilitas dikatakan reliabel apabila memberikan nilai cronbach's alpha di atas 0,60.

3. Uji asumsi klasik

a. Uji Normalitas

Uji Normalitas bertujuan untuk menguji apakah dalam model regresi, variabel pengganggu atau residual memiliki distribusi normal. Seperti diketahui bahwa uji $\mathrm{t}$ dan uji $\mathrm{F}$ mengasumsikan bahwa nilai residual mengikuti distribusi normal. Kalau asumsi ini dilanggar maka uji statistik menjadi tidak valid.

b. Uji Multikolinearitas

Uji Multikolinearitas bertujuan menguji apakah model regresi ditemukan adanya korelasi antar variabel bebas (independen). Meski regresi yang baik seharusnya tidak terjadi korelasi antar variabel bebas.

c. Uji Heteroskedastisitas

Uji Heteroskedastisitas bertujuan untuk menguji apakah dalam model regresi terjadi ketidaksamaan variance dari residual satu pengamatan ke pengamatan lain. Jika varience dari residual satu pengamatan ke pengamatan lain tetap, maka disebut homoskedastisitas dan jika berbeda, maka disebut heteroskedastisitas.

4. Analisis jalur (path analysis) adalah suatu analisis untuk melihat sejauh mana pengaruh komitmen organisasi dan lingkungan kerja terhadap kinerja pegawai melalui kepuasan kerja pada Kantor Pemerintah Kecamatan Camba Kabupaten Maros dengan menggunakan rumus Asra, dkk (2017:220) yaitu :

$$
\begin{aligned}
Y= & \beta_{0}+\beta_{1} X_{1}+\beta_{2} X_{2}+e \\
& Z=\beta_{0}+\beta_{1} X_{1}+\beta_{2} X_{2}+\beta_{3}+Y_{1}+e
\end{aligned}
$$

5. Pengujian hipotesis dilakukan dengan menggunakan dua pengujian yakni uji f (serempak) dan Uji t (parsial) yang dapat diuraikan adalah :

a. Uji t

Uji t digunakan untuk mengetahui apakah masingmasing variabel independen berpengaruh terhadap variabel dependen dalam regresi.

b. Uji $\mathrm{f}$

Uji serempak (Uji f) digunakan untuk mengetahui apakah seluruh variabel bebasnya secara bersamasama mempunyai pengaruh yang bermakna terhadap variabel terikat.

Koefisien determinasi (adjusted $\mathrm{R}^{2}$ ) $\quad$ Uji $\quad \mathrm{R}^{2}$ merupakan uji yang dilakukan terhadap model yang dibentuk dengan tujuan menjelaskan seberapa besar kontribusi dari variabel bebas yang diteliti terhadap variabel terikat. Nilai $R^{2}$ mempunyai range antara 0 sampai dengan $1\left(0 \leq R^{2} \geq 1\right)$. Semakin besar nilai $R^{2}$ maka semakin bagus model regresi yang digunakan. Sedangkan semakin kecil nilai $\mathrm{R}^{2}$ artinya variabel bebas yang digunakan terhadap variabel terikat semakin kecil. 


\section{HASIL DAN PEMBAHASAN}

Untuk mengetahui pengaruh antara komitmen organisasi, lingkungan kerja, kepuasan kerja terhadap kinerja pegawai. Berdasarkan hasil olahan data dengan menggunakan program SPSS maka dapat dijabarkan sebagai berikut : $\mathrm{Y}=2,782 \mathrm{~b}_{\mathrm{o}}+0,231 \mathrm{X}_{1}+0,254 \mathrm{X}_{2}+$ $0,385 \mathrm{X}_{3}$. Hasil persamaan regresi dapat diberikan penjelasan regresi yaitu : Konstan (bo) sebesar 2,782 hal ini berarti bahwa dengan adanya komitmen organisasi, lingkungan kerja dan kepuasan kerja maka kinerja pegawai sebesar $2,782 \%$. Koefisien regresi untuk variabel komitmen organisasi $\left(b_{1}\right)$ sebesar 0,231 yang berarti bahwa komitmen organisasi berpengaruh positif terhadap kinerja pegawai, dimana apabila tanggapan responden mengenai komitmen organisasi meningkat maka kinerja pegawai juga akan meningkat sebesar $0,231 \%$. Koefisien regresi untuk variabel lingkungan kerja $\left(b_{2}\right)$ sebesar 0,254 yang berarti bahwa lingkungan kerja berpengaruh positif terhadap kinerja pegawai, dimana apabila tanggapan responden mengenai lingkungan kerja ditingkatkan maka kinerja pegawai akan meningkat sebesar 0,254\%. Koefisien regresi untuk variabel kepuasan kerja $\left(b_{3}\right)$ sebesar 0,385 yang berarti bahwa kepuasan kerja berpengaruh positif terhadap kinerja pegawai, dimana apabila tanggapan responden mengenai kepusaan kerja ditingkatkan maka kinerja pegawai akan meningkat sebesar $0,385 \%$.

Uji korelasi dan koefisien determinasi dilakukan untuk mengetahui persentase sumbangan pengaruh variabel independen (variabel bebas) secara serentak terhadap variabel dependen (variabel terikat). Koefisien ini menunjukkan seberapa besar persentase variasi pengaruh komitmen organisasi, lingkungan kerja dan kepuasan kerja yang digunakan dalam model mampu menjelaskan variasi variabel kinerja pegawai pada Kantor Pemerintah Kecamatan Camba Kabupaten Maros. Dari hasil pengujian korelasi maka diperoleh nilai $\mathrm{R}=0,712$ yang menunjukkan bahwa $71,2 \%$ terdapat korelasi atau hubungan yang kuat komitmen organisasi, lingkungan kerja dan kepuasan kerja terhadap kinerja pegawai. Sedangkan koefisien determinasi yang dilihat dari nilai adjusted $\mathrm{R}^{2}=0,479$ yang diartikan bahwa variasi pengaruh kinerja pegawai dapat dijelaskan oleh variasi dari ketiga variabel independent yakni : komitmen kerja, lingkungan kerja dan kepuasan kerja, sedangkan sisanya sebesar $52,1 \%$ dapat dijelaskan oleh faktor-faktor lain yang tidak diteliti dalam penelitian ini.

a. Pengaruh Komitmen Organisasi Terhadap Kepuasan Kerja

Berdasarkan hasil penelitian yang dilakukan menemukan bahwa komitmen organisasi berpengaruh positif dan signifikan terhadap kepuasan kerja pada Kantor Pemerintah Kecamatan Camba Kabupaten Maros. Hal ini berarti bahwa semakin tinggi komitmen organisasi maka kepuasan kerja pegawai akan semakin meningkat. Temuan-temuan empirik membuktikan bahwa setiap pegawai memiliki komitmen organisasi yang tinggi, hal ini dapat dilihat bahwa rata-rata pegawai memberikan jawaban setuju mengenai rasa kesetiaan dan ketertarikan pegawai secara emosional terhadap pekerjaan, adanya rasa kepercayaan pegawai, setiap pegawai memiliki keyakinan dalam bekerja. Kemudian kepala kantor Pemerintah Kecamatan Camba Kabupaten Maros memiliki keunggulan dalam bekerja serta memiliki rasa keterikatan yang kuat baik terhadap organisasi maupun terhadap pekerjaan. Seorang pegawai yang memiliki komitmen yang kuat untuk tetap bekerja seperti merasakan kenyamanan dalam bekerja dan tentunya akan memberikan kepuasan bagi pegawai untuk menjalankan aktivitas kerjar sehari-hari. Teori yang dikemukakan oleh Badjuri dalam penelitian Arifah dan Romadhon (2015) yang menyatakan bahwa komitmen organisasional mempengaruhi berbagai perilaku penting agar organisasi dapat tumbuh mana kala harapan kerja terpenuhi oleh organisasi dengan baik. Selanjutnya dengan terpenuhinya harapan kerja ini akan menimbulkan kepuasan kerja. $M$. Aditya Putra Pratama, Fareshti Nurdiana Dihan (2017) dimana menemukan bahwa komitmen organisasi berpengaruh positif dan signifikan terhadap kepuasan kerja karyawan.

b. Pengaruh Lingkungan Kerja Terhadap Kepuasan Kerja

Hasil olahan data persamaan regresi maka diperoleh hasil bahwa lingkungan kerja mempunyai pengaruh yang positif dan signifikan terhadap kepuasan kerja pegawai pada Kantor Pemerintah Kecamatan Camba Kabupaten Maros. Hasil temuan empirik membuktikan bahwa lingkungan kerja yang ada pada Kantor Pemerintah Kecamatan Camba Kabupaten Maros sudah berjalan dengan baik, hal ini dapat dilihat dari jawaban responden yang sebagian besar memberikan jawaban setuju bahwa kondisi lingkungan kerja mendukung aktivitas kerja, fasilitas yang diberikan sesuai dengan kebutuhan kerja, penerangan di tempat kerja didukung dengan lampu dan bantuan sinar matahari, setiap pegawai dapat berinteraksi. Kemudian pimpinan selalu memberikan motivasi serta komunikasi terjalin dengan lancar, sehingga memberikan kepuasan kerja bagi setiap pegawai. Afandi (2018:64) mengemukakan bahwa lingkungan kerja merupakan faktor yang sangat penting di dalam perusahaan. Lingkungan kerja yang baik akan mendukung adanya tingkat produktivitas kerja yang tinggi, sehingga akan dapat meningkatkan produktivitas dari perusahaan yang bersangkutan. Lingkungan kerja yang menyenangkan bagi karyawan akan dapat menimbulkan rasa bergairah dalam bekerja sehingga memberikan kepuasan kerja bagi karyawan. Penelitian yang dilakukan oleh Lestari, dkk. (2014) dimana hasil penelitian menunjukkan bahwa lingkungan kerja mempengaruhi kepuasan kerja pada perusahaan Perbankan di kota Pekanbaru.

c. Pengaruh Komitmen Organisasi Terhadap Kinerja Pegawai

Hasil analisis regresi linear berganda diperoleh hasil koefisien regresi bahwa komitmen organisasi berpengaruh positif dan signifikan terhadap kinerja pegawaipada 
Kantor Pemerintah Kecamatan Camba Kabupaten Maros. Hal ini sesuai dengan teori yang dikemukakan oleh Luthans (2012) bahwa karyawan yang berkomitmen tinggi akan memiliki produktivitas kerja yang tinggi pula. Hasil penelitian empirik maka ditemukan bahwa komitmen kerja yang dimiliki oleh setiap pegawai sudah tinggi, alasannya karena setiap pegawai memiliki rasa keterikatan yang tinggi pada pekerjaan dan organisasi, serta senantiasa memiliki kesungguhan dalam bekerja, sehingga hal ini mempengaruhi peningkatan kinerja pegawai. Komitmen yang dimiliki oleh pegawai merupakan instrument yang penting untuk meningkatkan performance atau kinerja, karena pegawai dengan komitmen organisasional yang tinggi menghasilkan performa kerja pada Kantor Pemerintah Kecamatan Camba Kabupaten Maros. Penelitian ini sejalan dengan penelitian yang dilakukan oleh Reinhard Rais, dkk (2016) hasil penelitian menemukan bahwa komitmen Organisasi berpengaruh positif dan signifikan terhadap kinerja karyawan pada PT. PLN (Persero) Wilayah Suluttenggo.

d. Pengaruh Lingkungan Kerja Terhadap Kinerja

Pegawai

Lingkungan kerja berpengaruh positif dan signifikan terhadap kinerja pegawai pada pada Kantor Pemerintah Kecamatan Camba Kabupaten Maros. Semakin baik lingkungan kerja maka akan memberikan hasil kerja yang maksimal. Hal ini sesuai dengan teori yang dikemukakan oleh Nitisemito (2016:109) bahwa lingkungan kerja yang menyenangkan bagi pegawai melalui peningkatan hubungan yang harmonis dengan atasan, rekan kerja, maupun bawahan, serta didukung oleh sarana dan prasarana yang memadai yang ada di tempat kerja akan membawa dampak yang positif bagi pegawai, sehingga kinerja pegawai dapat meningkat. Hasil penelitian empirik menemukan bahwa lingkungan kerja sudah dapat menunjang aktivitas kerja sehari-hari di kantor, karena sudah terjalin komunikasi yang baik, kondisi kerja yang menyenangkan, terdapat fasilitas pendukung dalam bekerja, serta pencahayaan yang menunjang pegawai dalam menyelesaikan pekerjaan. Penelitian ini relevan dengan penelitian yang dilakukan oleh Chandra, Lion (2018)dimana hasil penelitian menemukan bahwa lingkungan kerja berpengaruh positif terhadap kinerja pegawai pada karyawan PMI Kota Yogyakarta.

e. Pengaruh Kepuasan Kerja Terhadap Kinerja Pegawai

Kepuasan kerja berpengaruh positif dan signifikan terhadap kinerja pegawai pada Kantor Pemerintah Kecamatan Camba Kabupaten Maros. Dimana semakin tinggi kepuasan kerja maka kinerja pegawai akan semakin meningkat. Hasil penelitian menemukan bahwa setiap pegawai merasa senang dengan pekerjaan saat ini, gaji yang diterima seimbang dengan tugsa-tugas yang dikerjakan, Kantor Pemerintah Kecamatan Camba selalu melakukan promosi jabatan. Kemudian selalu ada pengarahan dari supervisor atau pengawas, serta pekerjaan dapat diselesaikan sesuai dengan waktu yang ditentukan, dan ini berdampak terhadap peningkatan kinerja pegawai. Hal ini sesuai dengan teori yang dikemukakan oleh Sinambela (2012:255) mengatakan bahwa kepuasan kerja berkaitan erat dengan kinerja pegawai, alasannya karena kepuasan kerja merujuk kepada sikap umum seorang individu atau karyawan terhadap pekerjaan yang dilakukannya. Seseorang dengan tingkat kepuasan kerja tinggi menunjukkan sikap yang positif terhadap pekerjaan itu sendiri, sedangkan seseorang yang tidak puas dengan pekerjaannya menunjukkan sikap yang negatif terhadap pekerjaan itu. Sehingga dapat dikatakan bahwa kepuasan kerja yang tinggi akan berpengaruh terhadap kinerja karyawan. Penelitian yang dilakukan oleh Reinhard Rais, dkk (2016), hasil dari penelitian ini menunjukkan bahwa kepuasan kerja berpengaruh terhadap kinerja karyawan di PT. PLN (Persero) Wilayah Suluttenggo.

f. Pengaruh Komitmen Organisasi Terhadap Kinerja Pegawai Melalui Kepuasan Kerja

Berdasarkan hasil uji mediasi maka diperoleh hasil bahwa kepuasan kerja tidak dapat memediasi pengaruh komitmen organisasi terhadap kinerja pegawai khususnya Kantor Pemerintah Kecamatan Camba Kabupaten Maros. Hal ini sesuai dengan teori yang dikemukakan oleh Kristianto, et.al., (2013) bahwa kepuasan kerja dihasilkan dari persepsi karyawan mengenai seberapa baik pekerjaan mereka menyediakan hal yang dipandang penting. Variabel kepuasan kerja dapat menjadi variabel intervening antara pengaruh komitmen organisasional terhadap kinerja karyawan. Karyawan yang memiliki komitmen organisasional yang tinggi namun memiliki kepuasan kerja yang rendah akan menurunkan kinerja karyawan. Namun, jika karyawan memiliki komitmen organisasional yang tinggi dan memiliki kepuasan kerja yang tinggi tentunya juga akan meningkatkan kinerja karyawan. Penelitian Riswanto (2013) bahwa komitmen organisasi, kepuasan kerja dan kinerja merupakan hal yang tidak terpisahkan dari sebuah organisasi, karena dalam suatu organisasi membutuhkan hal-hal yang bisa memotivasi karyawan agar bisa bekerja dengan baik dan benar sehingga tujuan dari orgaisasi bisa tercapai dan mendapatkan hasil yang bagus. Semakin baik komitmen organisasi maka semakin baik kinerja kerja melalui kepuasan kerja yang dirasakan oleh karyawan. Penelitian M. Aditya Putra Pratama, Fareshti Nurdiana Dihan (2017) ada pengaruh tidak langsung yang signifikan dari komitmen organisasi terhadap kinerja melalui kepuasan karyawan sebagai variabel intervening. Sedangkan penelitian yang dilakukan oleh peneliti bahwa kepuasan kerja tidak dapat memediasi pengaruh komitmen organisasi terhadap kinerja pegawai khususnya Kantor Pemerintah Kecamatan Camba Kabupaten Maros.

g. Pengaruh lingkungan kerja terhadap kinerja pegawai melalui kepuasan kerja pada Kantor Pemerintah Kecamatan Camba Kabupaten Maros

Berdasarkan hasil uji mediasi pengaruh lingkungan kerja terhadap kinerja pegawai melalui kepuasan kerja pada Kantor Pemerintah Kecamatan Camba Kabupaten Maros, maka dapat dikatakan bahwa kepuasan kerja dapat memediasi pengaruh lingkungan kerja terhadap kinerja 
pegawai. Peningkatan lingkungan kerja akan diikuti oleh meningkatnya tingkat kepuasan kerja. Ini menunjukkan bahwa variabel lingkungan kerja memiliki pengaruh yang signifikan terhadap kepuasan kerja karyawan. Penelitian Mukti Wibowo (2014) memberikan sebuah implikasi bahwa lingkungan kerja berperan penting untuk meningkatkan kepuasan kerja karyawan. Hal ini terjadi karena apabila lingkungan kerja semakin baik, maka kepuasan kerja yang dirasakan oleh setiap karyawan pun juga akan semakin membaik, sehingga dengan adanya perasaan puas yang dirasakan oleh setiap karyawan dengan adanya lingkungan kerja yang nyaman tersebut maka secara langsung akan berdampak terhadap peningkatan kinerja karyawan dalam menjalankan aktivitas kerja sehari-hari di kantor. Sedangkan hasil penelitian yang dilakukan oleh peneliti bahwa kepuasan kerja dapat memediasi pengaruh lingkungan kerja terhadap kinerja pegawai pada Kantor Kecamatan Camba Kabupaten Maros.

\section{KESIMPULAN DAN SARAN}

Hasil penelitian menyimpulkan bahwa komitmen organisasi berpengaruh positif dan signifikan terhadap kepuasan kerja. Pengujian jalur analisis mengenai pengaruh lingkungan kerja terhadap kepuasan kerja. Temuan yang diperoleh dalam penelitian ini adalah lingkungan kerja berpengaruh positif dan signifikan terhadap kepuasan kerja. Pengujian jalur analisis mengenai komitmen organisasi terhadap kinerja pegawai, temuan ini menemukan bahwa komitmen organisasi berpengaruh positif dan signifikan terhadap kinerja pegawai. Pengujian jalur analisis yaitu pengaruh lingkungan kerja terhadap kinerja pegawai. Temuan dalam penelitian ini yang menemukan bahwa lingkungan kerja berpengaruh positif dan signifikan terhadap kinerja pegawai pada Kantor Pemerintah Kecamatan Camba Kabupaten Maros. Pengujian jalur analisis yaitu pengaruh kepuasan kerja terhadap kinerja pegawai yang diperoleh temuan dalam penelitian ini bahwa kepuasan kerja berpengaruh positif dan signifikan tehadap kinerja pegawai pada pada Kantor Pemerintah Kecamatan Camba Kabupaten Maros. Pengujian jalur analisis mengenai komitmen organisasi melalui kepuasan kerja terhadap kinerja pegawai yang menemukan bahwa kepuasan kerja tidak dapat memediasi pengaruh komitmen organisasi terhadap kinerja pegawai. Pengujian jalur analisis mengenai lingkungan kerja terhadap kinerja pegawai melalui kepuasan kerja, dimana temuan dalam penelitian ini menemukan bahwa kepuasan kerja dapat memediasi pengaruh lingkungan kerja terhadap kinerja pegawai. Maka saran-saran dari hasil penelitian disarankan agar untuk dapat meningkatkan komitmen organisasi perlunya meningkatkan kepercayaan kepada pegawai dalam penyelesaian pekerjaan yang diberikan. Sebaiknya Kantor Pemerintah Kecamatan Camba Kabupaten Maros lebih meningkatkan fasilitas kerja agar dapat meningkatkan aktivitas kerja. Perlunya pimpinan Kantor Pemerintah
Kecamatan Camba Kabupaten Maros lebih meningkatkan arahan yang jelas dalam pencapaian visi dan misi kantor. Disarankan agar perlunya meningkatkan kenyamanan kondisi pegawai dalam menunjang aktivitas kerja. Perlunya meningkatkan kualitas pegawai dalam penyelesaian pekerjaan guna menunjang kemampuan pegawai dalam penyelesaian pekerjaan.

\section{DAFTAR PUSTAKA}

Afandi Pandi, 2018. Manajemen Sumber Daya Manusia, Teori, Konsep dan Indikator, cetakan pertama, Pekanbaru Riau, Penerbit : Zanafa Publishing

Arifah,. D, A., dan Romadhon., C., (2015), Pengaruh Komitmen Organisasi, Komitmen Profesional dan Gaya Kepimpinan terhadap Kepuasan Kerja dengan Motivasi sebagai Variabel Interverning, Conference in Business, Accounting, and Management, 2 (1).

Asra Abuzar, 2017. Analisis Multivariabel Suatu Pengantar, Penerbit : In Media, Bogor

Chandra, Lion (2018)Pengaruh Lingkungan Kerja, Komitmen Organisasional dan Motivasi Kerja Terhadap Kinerja Karyawan Melalui Kepuasan Kerja Sebagai Variabel Intervening (Studi pada Karyawan PMI Kota Yogyakarta)Tesis Universitas Pembangunan Nasional "Veteran" Yogyakarta.

Fahmi, Irham. 2016. Manajemen Sumber Daya Manusia. Cetakan ke 11, Penerbit : Bumi Aksara, Jakarta

Kristianto., D. et.al. 2013. Pengaruh Kepuasan Kerja terhadap Kinerja Karyawan dengan Komitmen Organisasional sebagai Variabel Intervening (Studi pada RSUD Tugurejo Semarang).

Lestari, Indah Dwi, dkk 2014. Pengaruh Komitmen Organisasi, Lingkungan Kerja, Dan Kompetensi Terhadap Kinerja Karyawan Bagian Akuntansi Dengan Kepuasan Kerja Sebagai Variabel Moderating (Pada Perusahaan Perbankan Di Kota Pekanbaru). JOM FEKON Vol. 1 No. 2 Oktober 2014.

Luthans, Fred. 2012. Perilaku Organisasi, Alih Bahasa V.A Yuwono. Penerbit : Andi : Yogyakarta

M. Aditya Putra Pratama, Fareshti Nurdiana Dihan (2017) Pengaruh Komitmen Organisasional Dan Disiplin Kerja Terhadap Kinerja Karyawan Melalui Kepuasan Kerja Sebagai Variabel Intervening. Jurnal Bisnis Teori dan Implementasi, Home > Vol 8, No. 2(2017)

Marewa, Y. S., Saleh, Y., \& Abduh, T. (2019). Pengaruh Profesionalisme Dan Komitmen Organisasi Terhadap Kinerja Auditor Internal Dan Reward Sebagai Variabel Intervening (Studi Pada Kantor Inspektorat Provinsi Sulawesi Selatan). Indonesian Journal of Business and Management, 1(1), 53-56.

Nitisemito S, Alex. 206. Manajemen Personalia (Manajemen Sumber Daya Manusia), cetakan kesembilan, edisi ketiga, Penerbit : Ghalia Indonesia, Jakarta 
Pigome, hoseo, Sapiri, M., \& Abduh, T. (2019). Pengaruh Kecerdasan Emosional, Komitmen Organisasi Dan Organizational Citizenship Behavior Terhadap Kinerja Perawat Rumah Sakit Umum Daerah Kabupaten Paniai Propinsi Papua. Indonesian Journal of Business and Management, 1(2), 48-58.

Prawirosentono, Suyadi. 2017. Kinerja dan Motivasi Karyawan, Membangun Membangun Organisasi Kompetitif Era Perdagangan Bebas Dunia, edisi ketiga, cetakan kedua, Penerbit : BPFE, Yogyakarta

Reinhard Rais, dkk (2016) Komitmen Organisasi, Kepuasan Kerja dan Lingkungan Kerja Terhadap Kinerja Karyawan di PT. PLN (Persero) Wilayah Suluttenggo. Jurnal berkala Ilmiah Efisiensi, Vol.16 No.1. Tahun 2016.

Riswanto, Eka. 2013. pengaruh Komitmen Organisasi Terhadap Kinerja Melalui Kepuasan Kerja Karyawan Pada Bank Artha Graha International Tbk Pekanbaru.Jom FEKON Vol. 1 No. 5 Juli 2013.

Robbins, S.P. dan Timothy A. Judge, 2015. Perilaku Organisasi : Konsep, Kontroversi, Aplikasi. Alih Bahasa Hadyana Pujaatmaka dan Benyamin Molan. edisi Kedelapan. Jilid dua. Penerbit : Prenhallindo, Jakarta

Sinambela, Lijan Poltak. 2012. Kinerja Pegawai Teori Pengukuran dan Implikasi. Penerbit : Graha Ilmu. Yogyakarta

Sugiyono, 2016, Metode Penelitian Administrasi dilengkapi dengan Metode $\mathrm{R} \& \mathrm{D}$, penerbit : Alfabeta, Bandung.

Sutrisno, Edy. 2016. Manajemen Sumber Daya Manusia. Cetakan kedelapan, Penerbit : Kencana. Jakarta.

Wibowo. 2014. Perilaku Dalam Organisasi, edisi kedua, Penerbit : Rajawali Pers, Jakarta 